\title{
Negotiating Safety and Wellbeing: The Collaboration Between Faith-Based Communities and Public Health During the COVID-19 Pandemic
}

\author{
Salam El-Majzoub ${ }^{1}$ (D) - Lavanya Narasiah ${ }^{2} \cdot$ Alix Adrien $^{3} \cdot$ David Kaiser $^{4}$. \\ Cécile Rousseau ${ }^{5}$
}

Accepted: 16 September 2021 / Published online: 24 September 2021

(C) The Author(s), under exclusive licence to Springer Science+Business Media, LLC, part of Springer Nature 2021

\begin{abstract}
The COVID-19 pandemic led to lockdown measures where congregational faithbased activities were prohibited. With time, the collateral impacts of confinement emerged as priorities, and impositions had to be balanced with the collaboration of the population. In this process, faith-based organizations played a key role in encouraging their congregations to adhere to lockdown measures while fostering their mental wellbeing and resilience. This paper describes the process of establishing a collaborative negotiation among the Montreal Regional Public Health Unit, the police, and the Muslim and Jewish communities, examining the role of mediation in this context. Despite some obstacles, such as communication difficulties and decision-making limitations, the collaborative approach seems to buffer the escalation of intercommunity tension and to promote communities' commitment to physical distancing measures and should be considered in times of pandemic for a more inclusive public health approach.
\end{abstract}

Keywords COVID-19 · Religious communities · Public health · Collaboration · Mediation

\section{Introduction}

In the first phase of the COVID-19 pandemic, the urgency of limiting the transmission of the virus led to immediate and strict physical distancing measures in many countries, including Canada. The province of Quebec rapidly put in place public health measures, including a general confinement order, with good adherence from the population. However, as the confinement order extended, the collateral effects of

Salam El-Majzoub

Salam.el-majzoub@mail.mcgill.ca

Extended author information available on the last page of the article 
these measures on the psychosocial wellbeing of the population became increasingly evident. The pandemic and the related containment measures, such as self-isolation, quarantine and physical distancing, have been shown to lead to an increase in stress, distress, and loneliness; worsening of previous mental health issues; and an increase in family conflicts (Laforest, Roberge, and Maurice, 2020). These consequences seem to disproportionately affect minority groups because these groups experience multiple vulnerabilities (linguistic, migratory, employment-related, socioeconomic) that may make it harder for them to understand and apply public health measures (Cleveland, Hanley, Jaimes and Wolofsky, 2020; "Institut national d'excellence en santé et en services sociaux", 2020). Furthermore, while mental health needs grew during the crisis, barriers to accessing help also increased. Mental health services were often perceived as low priority, telehealth was prioritized indiscriminately, and individuals' fear of infection made it more difficult to access in-person care when needed (Laforest et al., 2020; Reger et al., 2020). Although these barriers impacted everyone, they did not impact everyone equally. Individuals from minority groups who have most of their mental health needs met through community support interventions and emphasis on spiritual wellbeing supported by faith-based organizations were significantly impacted when these resources became almost impossible to access (Cleveland et al., 2020; Madan, 2011).

Religious gatherings were banned for valid public health reasons: they present a high risk of viral transmission with the difficulty of respecting physical distancing measures in closed spaces. (Hernandez, Scarr, and Sharma, 2020). However, faith and spiritual practices are important individual coping mechanisms in times of crisis, especially for elderly persons and minority groups who may have stronger affiliations with religious groups than the general population. Furthermore, faithbased organizations may also provide frontline psychosocial services that are often more accessible and acceptable to individuals from minority communities (Madan, 2011; Wang et al., 2003). On a community level, collective religious practices play an important role in fostering connectedness and community resilience (Koenig, 2009; Sheikhi et al., 2020). To face adversity, religious communities have sought to reorganize their activities to foster spirituality and connectedness through virtual platforms (Campbell, 2020), as was the case in Quebec. However, some factors limited the outreach capacity of these new modalities, such as technological literacy and structural factors, including access to the internet (Girdhar, Srivastava, \& Sethi, 2020; Gunnell et al., 2020). Despite these challenges, many religious people have mentioned that their faith has been strengthened during the COVID-19 pandemic, as it served as a coping mechanism in uncertain times (Gecewicz, 2020; Pirutinsky et al., 2020). During the pandemic, international organizations have emphasized the key role of religious leaders in relaying public health information about COVID-19 to their communities and encouraging people to adhere to governmental measures ("World Health Organization", 2020b). Maintaining their support in a context of the unilateral imposition of measures that significantly limit their actions may, however, become difficult as time passes and the crisis endangers their mission and survival.

Balancing the risk to the safety of the population with its wellbeing is a challenging exercise during the COVID-19 pandemic because it requires ongoing negotiations in a dynamic, unpredictable and ever-evolving crisis. Beyond the 
challenges associated with uncertainty, the COVID-19 pandemic has shattered the social fabric of societies, provoking divisions around what was deemed essential during the confinement period. Often, voices from majority groups have prevailed; in other cases, some attention has been given to the specific needs of minorities (Cleveland et al., 2020; Luft, 2020). The processes leading to these delicate choices has not yet been described although some attention has been given in the literature to medical-religious partnerships in the context of the COVID19 pandemic (Monson, 2021; Galiatsatos, 2020). Further knowledge could help institutions promote a public health agenda while preserving social harmony and protecting the rights of minorities. In Quebec (Canada), a series of intersectional negotiations among health authorities, faith-based organizations, and sometimes police forces were conducted during the COVID-19 crisis in spring 2020. The main aim of this paper is to document these negotiation processes in terms of their benefits and limitations, with the objective of informing the implementation of future dialogues in times of crisis. More specifically, we aim to explore how these collaborative negotiations were established among the Montreal Regional Public Health Unit (PHU), a transcultural psychiatry team (TP), the police, and two different religious communities and to identify the outcomes, obstacles and facilitators.

\section{Methods}

\section{Setting}

This is a multicase observational report describing the negotiations between public health and religious communities by documenting the initiation of the negotiation, the actors, the processes and outcomes of the meetings (obstacles and facilitators) and the follow-up processes. This mediation initiative emerged in a crisis context from a previous partnership between the PHU and the TP, and the idea of writing up the experience as an observational report emerged, as some of the participants expressed the desire to share the lessons learned. As a community case report, there is no collection of human participants' data and no ethics approval. The process was documented with the verbal consent of all participants, and feedback on the article was sought with particular attention to including the voices of participants from the religious communities. The negotiation processes involved two faith-based communities in the greater Montreal area (Jewish and Muslim) and the PHU. Montreal is a major city in the province of Quebec and was at the epicenter of COVID-19 cases and deaths in Canada during the first wave of the pandemic. Strict physical distancing measures and closure of nonessential services, including places of worship, were imposed by the provincial government on March 13, which preceded important religious events, including Easter for the Christian communities, Passover for the Jewish community and the month of Ramadan for the Muslim community. Meetings of 
the PHU, the members of each religious community and other actors were organized remotely using the virtual platform Zoom in April 2020.

\section{The Institutional Actors}

Beyond the PHU, the negotiations involved two different sets of actors: (1) the Jewish community, the police and the TP and (2) the Muslim community and the TP.

\section{The Montreal Regional Public Health Unit}

The PHU has the legal mandate to protect and promote the health and wellbeing of the Montreal population while addressing social inequities. In the context of the pandemic, the PHU played a central role in supporting municipal and community partners and informing policy-making. Professionals from the emergency coordination center and the ethnocultural response team represented PHU during the meetings.

\section{The Transcultural Team}

The TP is composed of a psychiatrist, psychiatry residents, psychologists and social workers who are based in a highly multiethnic borough of Montreal called Parc-Extension and have expertise in intercommunity relationships and polarization (Rousseau et al., 2021). The team often mediates between majority and minority groups in socially divisive situations.

\section{The Police Force}

The municipal police of Montreal is divided into 31 local police stations. Representatives from local stations near where early outbreaks of COVID-19 occurred among Orthodox Jewish communities were present for the conversations with the Jewish community. The Montreal police also has a unit responsible for hate crimes and hate incidents, which was solicited in response to reported intercommunity tensions.

\section{Process Documentation}

The interventions were documented via field notes and diaries by observers of the meetings. Three participants from the transcultural team who acted as observers completed a grid for the Jewish community and the Muslim community. The grid has three sections: the initial requests and the organization of the meeting, the process and outcome of the dialogue and the mediation and the follow-up process. The questions are open-ended, and there is room in the grid for reflections and observations. The field notes and diaries were read repeatedly to identify 
emerging themes and were subsequently coded manually. A thematic analysis across cases was subsequently performed.

\section{Approach}

The TP used a transformative framework when approaching the mediation between different institutions and cultural groups with power differentials. They drew from the dialogic approach, first described by Mikhail Bakhtin. Bakhtin (Hermans and Hermans-Konopka, 2010) (Baxtin, [1934/35] 1981) theorizes that a person has multiple inner voices that reflect the many influences that shape their identities as well as the contexts in which they evolve: family, cultural group, religion, career, personal interests, etc. This particular perspective facilitates the acknowledgment of power relations and of personal and collective blind spots. Therefore, the emphasis in the interventions is not only on the content of what it being said. Rather, an effort is also made to understand the implicit meaning in the specific context and the interactions of the multitude of voices, identities and systems. This approach helps create a form of horizontal communication to move away from interactions where one party tries to convince the other of the superiority of its views. The objective is to launch an intercultural dialogue that can lead to the co-construction of creative solutions, drawing on the resilience and strengths of the communities (Broome et al., 2019).

\section{Results}

Three meetings were held on Zoom with the Jewish community on April 2nd, 7th and 14th, and two meetings were held with the Muslim community on April 15th (in French) and April 16th (in English). Religious authorities and several representatives of the communities were present. Seventy-three percent of the participants were male, and fifty-eight percent were in the 50-65-year-old age group. There were 8 participants from the Orthodox Jewish community of Montreal, 14 representing the Muslim community, and 3 Muslim participants representing the PHU and the TP. (Table 1).

\section{The Jewish Community}

\section{Process}

The first meeting was initiated by the PHU, whereas the following meetings were initiated by the community. The PHU approached the TP, asking them to mediate a meeting where they wanted to discuss in a culturally sensitive way the decision to close the mikvah. The mikvah is an indoor pool of water where observant married Jewish women take a ritual bath 7 days after the end of their menstruation to purify 
Table 1 Participant demographic characteristics

\begin{tabular}{|c|c|c|}
\hline Characteristics & \multicolumn{2}{|c|}{$\mathrm{N}(\%)$} \\
\hline \multicolumn{3}{|l|}{ Age } \\
\hline $20-35$ уо & 3 & $9 \%$ \\
\hline $35-50$ yо & 7 & $21 \%$ \\
\hline $50-65$ уо & 19 & $58 \%$ \\
\hline$>65$ & 4 & $12 \%$ \\
\hline \multicolumn{3}{|l|}{ Gender } \\
\hline Male & 24 & $73 \%$ \\
\hline Female & 9 & $27 \%$ \\
\hline \multicolumn{3}{|l|}{ Institution represented } \\
\hline Public health & 4 & $12 \%$ \\
\hline Transcultural psychiatry team & 5 & $15 \%$ \\
\hline Police & 2 & $6 \%$ \\
\hline Jewish community & 8 & $24 \%$ \\
\hline Muslim community & 14 & $42 \%$ \\
\hline \multicolumn{3}{|l|}{ Religious background } \\
\hline Jewish & 9 & $27 \%$ \\
\hline Muslim & 17 & $52 \%$ \\
\hline Hindu & 1 & $3 \%$ \\
\hline Christian & 6 & $18 \%$ \\
\hline \multicolumn{3}{|l|}{ Language used in meeting } \\
\hline English & 19 & $58 \%$ \\
\hline French & 5 & $15 \%$ \\
\hline Both & 9 & $27 \%$ \\
\hline \multicolumn{3}{|l|}{ Ethnicity } \\
\hline Caucasian & 14 & $42 \%$ \\
\hline Middle-east & 8 & $24 \%$ \\
\hline South Asian & 5 & $15 \%$ \\
\hline North African & 3 & $9 \%$ \\
\hline Sub-Saharan African & 2 & $6 \%$ \\
\hline Caribbean & 1 & $3 \%$ \\
\hline
\end{tabular}

themselves. Immersion usually occurs in a group under the supervision of an attendant. Very observant Jews cannot have sexual contact with a woman until she has performed her ritual cleansing.

\section{Spiritual Importance of Rituals}

The PHU started the meeting by announcing that the mikvah had to be closed for public health reasons and by reinforcing the importance of respecting the physical distancing measures during Passover. Rabbinic authorities defended the spiritual importance of the mikvah and referred to how they were kept open in Israel. The TP highlighted the conflict among sanitary safety, spiritual needs and the prejudices of the host society 
toward the Jewish community, which were exacerbated by the fact that the community was one of the first to be severely affected by outbreaks in Montreal. The TP invited both parties to find a solution that would be acceptable from a public health perspective while pushing the majority's position slightly out of its comfort zone by endorsing the mikvah as an essential religious practice. The community suggested ways of keeping the mikvah safely open by having individual appointments and implementing distancing and more rigorous disinfection and cleaning. The community also explored ways of continuing communal prayers by praying together on balconies, thus respecting physical distancing. The PHU agreed that these adjustments would respect public health directives and stated that they would support this position.

\section{Experiences of Discrimination}

In addition to the mikvah, the TP explored the impact of the negative media coverage and of the profiling of the Jewish families. This intervention uncovered intercommunity tensions, and the TP suggested follow-up meetings with the police to address the upsurge in hate crime and incidents and to buffer the profiling while endorsing respect for the law. The police had noticed no increase in reports of hate crimes or incidents by the Jewish community, which the TP linked to possible fear and past negative experiences with the police while inviting the community representative to speak up in order to collectively help restore a feeling of community safety. Thereafter, the community actors described numerous incidents of discrimination and of unfounded accusations made by the neighborhood for what was perceived as a lack of respect for the physical distancing measures. Orthodox Jewish families in the neighborhood have large households, and the number of people congregating made the neighbors nervous. The police would check on the complaints visibly and loudly, sometimes with multiple police cars that further terrified the community while increasing prejudice toward them. This opened a dialogue about the duty of the police to verify complaints versus the stigmatization (or discrimination) the community felt from their presence.

\section{Outcomes}

Regarding the outcomes, the meetings did not lead to the immediate reopening of the mikvah, as the government of Quebec opted to maintain a complete ban on all religious activities. The PHU stayed in regular contact with the community to answer questions regarding governmental measures, and the mikvah reopened in June as part of the deconfinement plan. The police made themselves less visible in their interventions, and the community was encouraged to file reports of phone harassment and hate incidents. The community respected public health measures during Passover. However, the discontent of the neighborhood toward the Jewish community and neighbors' negative perceptions continued and were made known to the TP through a neighborhood collaboration network that is ongoing. 


\section{The Muslim Community}

\section{Process}

The PHU considered that the intervention with the Jewish community was helpful and asked the TP to mediate a meeting with the Muslim community in anticipation of the month of Ramadan starting on April 24 to reinforce respect for physical distancing measures. The TP presented the meeting as an invitation to see how the community was impacted by the pandemic and the public health measures and to explore what was planned for Ramadan. Discrimination against Muslim communities was also mentioned.

\section{The Multiple Roles Played by the Place of Worship}

The recurrent themes raised by the community participants were the importance of mosques and imams not only for spiritual reasons but also for social and community needs - to provide social support for vulnerable individuals in the form of food, family conflict resolution, marriages/divorces/funerals and individual counseling. They found the closure of the mosques challenging as some imams could not talk to their congregants without being physically at the mosque, and they wondered if they could still provide food boxes and cook food for the breaking of the fast, Iftar, as they usually do every night of Ramadan. Additionally, some expressed their worry about the financial health of their mosques, as most of the donations that maintain them throughout the year are collected in person during the daily evening communal prayers of Ramadan, considered the month of charity. Many of the mosques had set up virtual religious services but insisted on the limits of these interventions, especially for elderly and isolated individuals. They did not report an increase in intercommunity tensions or discrimination. The PHU expressed concerns regarding the physical presence of community members in the mosques and the fact that such would constitute a precedent vis-à-vis other faith groups.

\section{Equity Between Faith-Based Organizations}

The TP thus proposed framing the response to the community's demands in terms of three categories: yes/no/maybe. For the yes, the PHU gave the green light to open mosque kitchens to cook Iftar meals for vulnerable people that could be picked up and to distribute food boxes using sanitary protocols. The TP suggested that the community members inform the police of their activities to avoid denunciation by neighbors. For the no, it was reiterated that gatherings were not allowed except with members of the same household and that the mosques could not be reopened at this point. The PHU and TP cited equity between faith-based organizations in justifying what was allowed, a position that was not well received by community representatives. For the maybe, the TP invited the community to 
submit suggestions on how they would apply sanitary measures to ensure that the activities they wished to resume were safe enough and would have more benefits than harms and proposed that the PHU would subsequently analyze the situation and respond with its rationale. Many imams wanted to offer individual spiritual support at the mosques. The TP validated the key role of the spiritual leaders in maintaining the psychosocial wellbeing of their community.

\section{Outcomes}

One mosque submitted a formal request for small group (5-10 individuals) gatherings at the mosque by appointment for worship with physical distancing. This was responded to with a grid explaining how the risks of such activity would outweigh the benefits. Some members of the community expressed gratitude for the meetings and went on to organize food banks and Iftar distribution during the month of Ramadan. The community did not request follow-up meetings. There were no denunciations from the neighbors or complaints to the police during Ramadan. The festivities of the end of Ramadan coincided with the first phase of deconfinement in Quebec, where 10 people from three different households were allowed to gather outdoors while maintaining physical distancing. This was welcomed very positively by the community.

Ultimately, these experiences led to formalizing the involvement of the TP with the creation of a program named CoVivre. CoVivre is a financed project that works on addressing inequities experienced by marginalized groups in the context of the pandemic by acting as a catalyst for actions and partnerships with key actors. These experiences also led to the writing of a mediation guide in collaboration with public health.

\section{Discussion}

The initiative of the PHU to discuss the impact of the COVID-19 public health measures with minority faith-based communities ahead of important religious celebrations was an innovative idea that was generally well received by these communities. They were appreciative of the fact that their voices were considered, even if the outcome was not what they had requested. In Quebec, as in other Western countries, religious organizations are at the sidelines, often perceived negatively by the general population, who have bitter memories of still-recent times when religion represented a dominant and oppressive power (Geddes, 2009; Zine, 2012). In a public health crisis situation, not only do the needs of the majority dominate and influence what is perceived as essential, but prejudices towards the Other can be exacerbated by conspiracy theories attributing the blame to traditional figures of the villain (most often Jews but also often Muslims) (Bieber, 2020; Schwartz, 2020; Van Bavel et al., 2020). Religious communities can perceive as inequitable authorizations to opening places such as golf courses or public gardens while places of worship remain closed. These factors could ultimately lead to disengagement in the fight against COVID-19. The lessons learned from other pandemics, such as that of Ebola, show 
that reciprocity with the population is one of the keys to success in order to better engage the latter in preventive measures to contain the pandemic (Ryan et al., 2019; Wilkinson, Parker, Martineau, and Leach, 2017). The lack of support of religious leaders for public health measures can make it more difficult to create a bond of trust with some minority communities. This could be detrimental to achieving a commitment from the population to respect the control measures advocated by public health authorities, which is one of the conditions for easing the lockdown measures (deconfinement) ("World Health Organization", 2020a). Thus, in itself, the simple benefits of being actively listened to and considered by institutions that are often perceived as serving mainly the majority can reduce tensions and increase collaboration and trust with religious communities.

The collaborative approach led to open conversations that gave an overview of the challenges experienced by religious communities and of the difficulties associated with supporting equity and public health principles at the institutional and government levels. Although first seen as a means to convince religious communities to implement public health measures, the meetings were a learning process for the involved health institutions and police force, who had to respectfully consider the priorities of the communities and the experiences of their members. The negotiations were beneficial in fostering recognition of the common social and community support agenda of faith-based communities that might have been overlooked by the government when the decisions were made to close places of worship. The PHU was able to correct this by giving faith-based organizations the same permissions as other community organizations (e.g., food banks, public kitchens). The negotiations also helped improve the relationship between the Jewish community and the police through more sensitive police interventions and addressing the upsurge in hate crime and incidents directed toward the community.

Traditionally, faith-based organizations are solicited for partnerships by health departments for health promotion purposes in the US (Barnes and Curtis, 2009), and such partnerships are particularly impactful in Black protestant churches (Darnell et al., 2006; Resnicow et al., 2004). Community engagement with faith-based organizations, among other strategies, has also been promoted as a key element of disaster and epidemic responses ("Centers for Disease Control and Prevention", 2010; Gillespie et al., 2016; Wiginton et al., 2019). This strategy has been used in the response to COVID-19 by some health institutions to help local faith-based organizations adapt to The Centers for Disease Control and Prevention (CDC) guidance (Monson, 2021; Galiatsatos, 2020). Stajura et al. (2012) explored how community-based organizations and faith-based organizations perceived collaboration with local health departments for disaster relief and found that a bidirectional relationship matters the most for participants. More often, however, local health departments use faith-based organizations as information disseminators while underestimating the capacity of these organizations to be active participants in emergency response, which leads to unsatisfactory partnerships. Lessons learned from these partnerships with faith-based communities highlight the need to identify legitimate leaders, listen to the needs of all parties, foster a bidirectional relationship and avoid top-down imposition of solutions in a one-size fits all model (Wilkinson et al., 2017). Other examples can be found of similar compromise processes with 
faith-based organizations during the first wave of the pandemic (Galiatsatos, 2020; Cornwell, 2020; Saeed, 2020). Some of these initiatives originated with local houses of worship who lobbied their local authorities with suggestions that did not jeopardize safety but could increase wellbeing. Sometimes this led to backlash from the majority, which illustrates the need to address intercommunity tensions within these initiatives (Allen, 2020).

Mediation can play an important role in promoting these elements through a collaborative approach. In this context, mediation by the TP helped balance the health and the wellness messages to acknowledge both and propose a middle ground solution that honored the real worries on both sides. The significant discrimination experienced by the communities and the associated structural discrimination was always at the forefront (Curtis et al., 2019). This recognition inverted the implicit positioning in which the communities were expecting to be lectured by the health institutions because their traditions and practices were (or could be) violations of the law. This acknowledgment of the possible absence of cultural safety in the encounter may have reduced distrust toward the PHU and emphasized in the community's eyes its interest in community wellbeing, which is also in its mandate.

\section{Study Limitations}

The absence of decision-makers in these negotiations was an obstacle to putting in motion suggestions from the community that were acceptable from a public health lens, such as opening the mikvah and providing individual in-person counseling. The meetings led the PHU and TP to recognize the importance of individual spiritual counseling from faith-based leaders. Thus, an evidence-based argument for individual counseling was built to continue advocating for the inclusion of religious communities and community organizations' activities within the governmental deconfinement plan, with some delays related to institutional barriers.

Although some members of the majority community were present representing the institutions in these meetings, it could have been beneficial to have people representing the neighborhoods that were experiencing increased intercommunity tension to work on the underlying issues with religious communities that were perceived to be putting the whole neighborhood at risk.

Additionally, virtual meetings posed communication challenges that grew with the number of participants in the meeting. The lack of subsequent requests from the Muslim community may reflect these communication challenges. The community's participants might have been satisfied with only clarifying some of the rules and stating their needs, and they did not request further meetings because they did not expect to be able to make more gains or because they did not wish to be too visible, having endured more than their share of discrimination (Moreau, 2020; Samari et al., 2018). Follow-up meetings could have helped clarify these hypotheses and kept the dialogue open. 


\section{Conclusion}

In a health crisis such as COVID-19 that disproportionately impacts minority communities, the collaboration process with faith-based communities can provide a voice to some marginalized groups and promote an inclusive public health approach (Curtis et al., 2019; Weinberger-Litman et al., 2020). These collaborative approaches should try to include actors from all sectors, such as decision-makers and representatives of the majority, to build bridges among them. However, these processes come with limitations stemming from a rapidly evolving health situation requiring quick decision making. Dialogue has to remain open with regular iterations and follow-ups on suggestions and decisions. Consultation and mediation can be the first steps in fostering mutual trust between minority communities and public institutions to prepare for subsequent waves of viral transmission and future crises.

Acknowledgements The authors would like to extend their gratitude to all the participants from the religious communities with special thanks to Rabbi Saul Emanuel, Samer Majzoub and Imam Imran Shariff. We would like to acknowledge the support of Dr. Ahmed Faress, Dr. Christian Desmarais, Anousheh Machouf and Marie-Hélène Rivest in organising the meetings and contributing to process documentation.

Authors' Contributions All authors contributed to the study conception and design. Material preparation and data collection were performed by SEM, CR and LN. The first draft of the manuscript was written by SEM and all authors commented on previous versions of the manuscript. All authors read and approved the final manuscript.

Funding The authors did not receive support from any organization for the submitted work.

Data Availability Documentation of the meetings are available for review.

Code Availability Not applicable.

\section{Declarations}

Conflict of interest The authors have no conflicts of interest to declare that are relevant to the content of this article.

Ethics Approval This article is a practice description in the form of a community case report and does not involve collected data or biological material of human participants, therefore there is no ethics approval. This community case report was performed in line with the Declaration of Helsinki. Participants' feedback on the article was sought with particular effort to include the voice of participants from the religious communities.

Informed Consent This article is written with the verbal consent of all participants: the Montreal Regional Public Health Unit, the transcultural psychiatry team and the participants from the two religious communities.

\section{References}

Allen, K. (2020, May 5). Mississauga's diversity committee set to look at decision to relax noise bylaws to allow call to prayer in Ramadan. The Star. Retrieved from https:/www.thestar.com/news/gta/ 
2020/05/05/mississauga-set-to-have-its-diversity-committee-look-at-decision-to-relax-noise-bylawsto-allow-the-call-to-prayer-during-ramadan.html

Barnes, P. A., \& Curtis, A. B. (2009). A national examination of partnerships among local health departments and faith communities in the United States. Journal of Public Health Management and Practice, 15(3), 253-263. https://doi.org/10.1097/01.PHH.0000349740.19361.ac

Baxtin, M. ([1934/35] 1981). "Discourse in the Novel." In The Dialogic Imagination: Four Essays. (pp. 259-422). Austin: U of Texas.

Bieber, F. (2020). Global Nationalism in Times of the COVID-19 Pandemic. Nationalities Papers. https:// doi.org/10.1017/nps.2020.35

Broome, B. J., Derk, I., Razzante, R. J., Steiner, E., Taylor, J., \& Zamora, A. (2019). Building an inclusive climate for intercultural dialogue: A participant-generated framework. Negotiation and Conflict Management Research, 12(3), 234-255. https://doi.org/10.1111/ncmr.12158

Campbell, H. (2020). The Distanced Church: Reflections on Doing Church Online: Digital Religion Publications. https://doi.org/10.21423/distancedchurch

Centers for Disease Control and Prevention. (2010). Public Health Workbook to Define, Locate and Reach Special, Vulnerable, and At-Risk Populations in an Emergency. Atlanta, GA, USA: Centers for Disease Control and Prevention

Cleveland, J., Hanley, J., Jaimes, A., \& Wolofsky, T. (2020). Impacts de la crise de la COVID-19 sur les «communautés culturelles» montréalaises-Enquête sur les facteurs socioculturels et structurels affectant les groupes vulnérables. Institut universitaire Sherpa. ISBN 978-2-9819166-0-0 (online) Retrieved from https://sherpa-recherche.com/en/publication/impacts-de-la-crise-de-la-covid-19-surles-communautes-culturelles-montrealaises/

Cornwell, S. (2020, April 29). Mississauga allows mosques to broadcast evening call to prayer during Ramadan. The Star. Retrieved from https://www.thestar.com/news/gta/2020/04/29/mississaugaallows-mosques-to-broadcast-evening-call-to-prayer-during-ramadan.html

Curtis, E., Jones, R., Tipene-Leach, D., Walker, C., Loring, B., Paine, S. J., \& Reid, P. (2019). Why cultural safety rather than cultural competency is required to achieve health equity: A literature review and recommended definition. Int J Equity Health, 18(1), 174. https://doi.org/10.1186/ s12939-019-1082-3

Darnell, J. S., Chang, C. H., \& Calhoun, E. A. (2006). Knowledge about breast cancer and participation in a faith-based breast cancer program and other predictors of mammography screening among African American women and Latinas. Health Promotion Practice, 7(3 Suppl), 201S-212S. https:// doi.org/10.1177/1524839906288693

Galiatsatos, P., Monson, K., Oluyinka, M., et al. (2020). Community Calls: Lessons and Insights Gained from a Medical-Religious Community Engagement During the COVID-19 Pandemic. Journal of Religion and Health, 59, 2256-2262. https://doi.org/10.1007/s10943-020-01057-w

Gecewicz, C. (2020, April 30). Few Americans say their house of worship is open, but a quarter say their faith has grown amid pandemic. Pew Research Center. Retrieved from https://www.pewresearch. org/fact-tank/2020/04/30/few-americans-say-their-house-of-worship-is-open-but-a-quarter-saytheir-religious-faith-has-grown-amid-pandemic/

Geddes, J. (2009). April 28). What Canadians think of Sikhs, Jews, Christians. Muslims. Macleans, 4, $20-24$.

Gillespie, A. M., Obregon, R., El Asawi, R., Richey, C., Manoncourt, E., Joshi, K., \& Quereshi, S. (2016). Social Mobilization and Community Engagement Central to the Ebola Response in West Africa: Lessons for Future Public Health Emergencies. Glob Health Sci Pract, 4(4), 626-646. https://doi.org/10.9745/GHSP-D-16-00226

Girdhar, R., Srivastava, V., \& Sethi, S. (2020). Managing mental health issues among elderly during COVID-19 pandemic. Journal of Geriatric Care and Research, 7(1), 32-35.

Gunnell, D., Appleby, L., Arensman, E., Hawton, K., John, A., Kapur, N., \& Collaboration, C.-S.P.R. (2020). Suicide risk and prevention during the COVID-19 pandemic. Lancet Psychiatry, 7(6), 468471. https://doi.org/10.1016/S2215-0366(20)30171-1

Hermans, H., \& Hermans-Konopka, A. (2010). Dialogical Self Theory: Positioning and Counter-Positioning in a Globalizing Society: Cambridge University Press. https://doi.org/10.1017/CBO9780511 712142

Hernandez, M., Scarr, S., \& Sharma, M. (2020, March 20). The Korean clusters: How coronavirus cases exploded in South Korea churches and hospitals. Reuters Graphics. Retrieved from https://graphics. reuters.com/CHINA-HEALTH-SOUTHKOREA-CLUSTERS/0100B5G33SB/index.html 
Institut national d'excellence en santé et en services sociaux (INESSS). (2020). COVID-19 et les facteurs approches favorisants l'observance des mesures de précaution et de protection auprès des personnes en situation de vulnérabilité. Quebec: Institut national d'excellence en santé et en services sociaux. Retrieved from https://www.inesss.qc.ca/fileadmin/doc/INESSS/COVID-19/COVID-19_ INESSS_Observance.pdf

Koenig, H. G. (2009). Research on religion, spirituality, and mental health: A review. Canadian Journal of Psychiatry, 54(5), 283-291. https://doi.org/10.1177/070674370905400502

Laforest, J., Roberge, M., \& Maurice, P. (2020). Réponse rapide: COVID-19 et répercussions psychosociales. Québec: Institut national de santé publique du Québec. Retrieved from https://www.inspq.qc. $\mathrm{ca} /$ sites/default/files/covid/3018-repercussions-psychosociales-covid19.pdf

Luft, A. (2020, May 12). COVID-19 hits poorer Montreal boroughs hardest, data reveals, with Montreal North bearing the brunt. CTV News Montreal. Retrieved from https://montreal.ctvnews.ca/ covid-19/covid-19-hits-poorer-montreal-boroughs-hardest-data-reveals-with-montreal-northbearing-the-brunt-1.4935066? cache=yes

Madan, A. (2011). Mental health interventions in Canada for migrants affected by state-sanctioned violence: An effectiveness study. Ethnicity and Inequalities in Health and Social Care, 4(3), 112-126. https://doi.org/10.1108/17570981111249257

Monson, K., Oluyinka, M., Negro, D., et al. (2021). Congregational COVID-19 Conversations: Utilization of Medical-Religious Partnerships during the SARS-CoV-2 Pandemic. Journal of Religion and Health. https://doi.org/10.1007/s10943-021-01290-x

Moreau, G. (2020). Police-reported hate crime in Canada, 2018. Statistics Canada, Catalogue no. 85-002-X(1209-6393). Retrieved from https://www150.statcan.gc.ca/n1/pub/85-002-x/2020001/ article/00003-eng.htm

Pirutinsky, S., Cherniak, A. D., \& Rosmarin, D. H. (2020). COVID-19, Mental Health, and Religious Coping Among American Orthodox Jews. Journal of Religion and Health, 59(5), 2288-2301. https://doi.org/10.1007/s10943-020-01070-Z

Reger, M. A., Stanley, I. H., \& Joiner, T. E. (2020). Suicide Mortality and Coronavirus Disease 2019-A Perfect Storm? JAMA Psychiatry. https://doi.org/10.1001/jamapsychiatry.2020.1060

Resnicow, K., Campbell, M., Carr, C., McCarty, F., Wang, T., Periasamy, S., \& Stables, G. (2004). Body and soul A dietary intervention conducted through African-American churches. Am J Prev Med, 27(2), 97-105.

Rousseau, C., Savard, C., Bonnel, A., Horne, R., Machouf, A., \& Rivest, M.-H. (2021). Clinical Intervention to Adress Violent Radicalization: the Quebec Model. In K. Bhui \& D. Bhugra (Eds.), Terrorism, Violent Radicalization and Mental Health: Oxford University Press. https://doi.org/ 10.1093/med/9780198845706.001.0001

Ryan, M. J., Giles-Vernick, T., \& Graham, J. E. (2019). Technologies of trust in epidemic response: Openness, reflexivity and accountability during the 2014-2016 Ebola outbreak in West Africa. BMJ Global Health, 4(1), e001272. https://doi.org/10.1136/bmjgh-2018-001272

Saeed, A. (2020, May 26). Coronavirus: German Ikea car park used for mass Eid prayer. $B B C$. Retrieved from https://www.bbc.com/news/world-europe-52759511

Samari, G., Alcala, H. E., \& Sharif, M. Z. (2018). Islamophobia, Health, and Public Health: A Systematic Literature Review. American Journal of Public Health, 108(6), e1-e9. https://doi.org/10. 2105/AJPH.2018.304402

Schwartz, F. (2020, April 20). Coronavirus sparks rise in anti-Semitic sentiment, Researchers say. The Wall Street Journal.

Sheikhi, R. A., Seyedin, H., Qanizadeh, G., \& Jahangiri, K. (2020). Role of Religious Institutions in Disaster Risk Management: A Systematic Review. Disaster Medicine and Public Health Preparedness. https://doi.org/10.1017/dmp.2019.145

Stajura, M., Glik, D., Eisenman, D., Prelip, M., Martel, A., \& Sammartinova, J. (2012). Perspectives of community- and faith-based organizations about partnering with local health departments for disasters. International Journal of Environmental Research and Public Health, 9(7), 2293-2311. https://doi.org/10.3390/ijerph9072293

Van Bavel, J. J., Baicker, K., Boggio, P. S., Capraro, V., Cichocka, A., Cikara, M., \& Druckman, J. N. (2020). Using social and behavioural science to support COVID-19 pandemic response. Nature Human Behaviour, 4(5), 460-471. https://doi.org/10.1038/s41562-020-0884-z

Wang, P. S., Berglund, P. A., \& Kessler, R. C. (2003). Patterns and correlates of contacting clergy for mental disorders in the United States. Health Services Research, 38(2), 647-673. https://doi.org/ $10.1111 / 1475-6773.00138$ 
Weinberger-Litman, S. L., Litman, L., Rosen, Z., Rosmarin, D. H., \& Rosenzweig, C. (2020). A Look at the First Quarantined Community in the USA: Response of Religious Communal Organizations and Implications for Public Health During the COVID-19 Pandemic. Journal of Religion and Health, 59(5), 2269-2282. https://doi.org/10.1007/s10943-020-01064-X

Wiginton, J. M., King, E. J., \& Fuller, A. O. (2019). "We can act different from what we used to": Findings from experiences of religious leader participants in an HIV-prevention intervention in Zambia. Global Public Health, 14(5), 636-648. https://doi.org/10.1080/17441692.2018.1524921

Wilkinson, A., Parker, M., Martineau, F., \& Leach, M. (2017). Engaging "communities": anthropological insights from the West African Ebola epidemic. Philos Trans $R$ Soc Lond B Biol Sci. https://doi.org/10.1098/rstb.2016.0305

World Health Organization. (2020a). COVID-19 Strategy Update. Geneva, Switzerland: World Health Organization Retrieved from https://www.who.int/docs/default-source/coronaviruse/covid-strategyupdate-14april2020.pdf?sfvrsn=29da3ba0_19\&download=true

World Health Organization. (2020b). Practical considerations and recommendations for religious leaders and faith-based communities in the context of COVID-19: Interim Guidance. (WHO/2019-nCoV/ Religious_Leaders/2020.1). Geneva, Switzerland: World Health Organization Retrieved from https://www.who.int/publications-detail/practical-considerations-and-recommendations-for-relig ious-leaders-and-faith-based-communities-in-the-context-of-covid-19

Zine, J. (2012). Islam in the hinterlands: Exploring Muslim cultural politics in Canada: UBC Press. ISBN, 0774822724, 9780774822725 .

Publisher's Note Springer Nature remains neutral with regard to jurisdictional claims in published maps and institutional affiliations.

\section{Authors and Affiliations}

\section{Salam El-Majzoub ${ }^{1}$ (D) Lavanya Narasiah ${ }^{2} \cdot$ Alix Adrien $^{3} \cdot$ David Kaiser $^{4}$. Cécile Rousseau ${ }^{5}$}

Lavanya Narasiah

Lavanya.narasiah.ccsmtl@ssss.gouv.qc.ca

Alix Adrien

Alix.Adrien.ccsmtl@ssss.gouv.qc.ca

David Kaiser

david.kaiser.ccsmtl@ssss.gouv.qc.ca

Cécile Rousseau

Cecile.rousseau@mcgill.ca

1 Department of Psychiatry, McGill University, Montreal, QC, Canada

2 Faculty of Medicine, McGill University, Montreal, QC, Canada

3 Department of Epidemiology, Biostatics and Occupational Health, McGill University, Montreal, QC, Canada

4 Public Health School- Department of Social and Preventative Medicine, Université de Montréal, Montreal, QC, Canada

5 Division of Social and Cultural Psychiatry, McGill University, Montreal, QC, Canada 